\title{
How Social Studies Teachers Reflect Their Immediate Environment: Kirıkkale Case
}

\author{
Gün Erol Şahin \\ Kırıkkale Directorate of National Education, Ministry of Education, Kırlkkale, Turkey \\ ORCID ID: 0000-0003-0932-7221
}

Çağr1 Öztürk Demirbaş*

Faculty of Education, Ahi Evran Üniversity, Kırşehir, Turkey ORCID ID: 0000-0001-8719-4167

Article history

Received:

25.05.2020

Received in revised form: 18.09.2020

Accepted:

20.09.2020

Key words:

Geography, geography education, social studies, social studies teacher, immediate environment, local geography
The study aimed to investigate how social studies teachers give information about the immediate environment in lessons and determine course objectives through non-formal school activities. The study sample consisted of 38 social studies teachers working in Kirıkkale province in the 2018-2019 academic year. The data were analyzed with content analysis methods. The data were collected with a semi-structured interview form, were processed in SPSS 17 and Microsoft Excel software and interpreted in relation to the relevant the literature. In the interview form, the teachers were grouped by certain variables: gender, professional experience, and settlement type of school. The study concluded that social studies teachers did not have adequate knowledge about the immediate environment and thus they could not transfer it to students. Although participant social studies teachers claimed to give information and examples during the course, their students expressed that their teachers did not give any examples. The study results also indicated that teachers did not sufficiently organize non-formal school activities to teach the immediate environment. Thusly, it is suggested that social studies teachers should be assisted in learning the immediate environment and should participate in training on non-formal teaching methods.

\section{Introduction}

The primary purpose of the schools affiliated to the Ministry of National Education (MoNE) is to prepare students for life and educate future generations. The life that is dealt in line with this goal can be divided into two main parts: physical and social

\footnotetext{
*Correspondency: cagri-79@ hotmail.com
} 
environment. In this regard, the social environment consists of the human environment, such as the student's family, friends, future work life, and the physical environment reflecting the geographical environment. In other words, the physical environment is where human beings carry out all their activities from birth to death. According to Şahin \& Öztürk Demirbaş (2019), the environment, which humans meet with birth, expands from near to far areas. As they interact with their environment, their life experiences also enhance. The schools aim to prepare students for life, so they should offer education by being aware of the expansion of this environmental knowledge.

Doğanay \& Doğanay (2015) point out that human beings lived under the control of the geographical environment and struggle with them. Individuals take many precautions, from food to clothing, from sheltering to behaviors and transportation, considering these geographical and environmental factors. If individuals do not gain a certain level of geography knowledge at schools, they may not realize that geographical elements surround one through their all four sides. According to the Ministry of National Education (2019), the term 'geography' is a science field dealing with human activities in nature. Besides, the science of geography affects human life and teaches people natural and human factors to regulate their lives according to these. Therefore, teachers who play a crucial role in preparing students for life must consider the geographical environment elements while carrying out educational activities.

The integration of geography into the curriculums started with life sciences lessons and then continued with social studies lessons delivered at the $4^{\text {th }}$-grade. The social studies course introduces the students with geography. Students may have difficulties making sense of geographic information when they encounter geography for the first time, so teachers should consider two critical factors in overcoming these challenges. The first is to teach the immediate environment and geographical subjects within the scope of the from-near-to-far principle. The second step is to help students learn by making a better sense of their immediate surroundings. In fact, it is the most critical step for non-formal school activities.

In teaching geography, the subjects should start from the geographical characteristics of where the students live because learning the immediate environment is the first stage of establishing a life in harmony with that environment. Making sense of the universe and the world starts with getting to know and learn where one lives. This beginning should proceed in a line from local to regional, from regional to national, from national to global terms. It is called the from-near-to-far principle and plays a crucial role in teaching geographical subjects. It is also closely related to the place-based education method (Öztürk Demirbaş \& Şahin, 2019). It is associated with many different methods and techniques in the literature, including authentic education, local geography, hometown education, place-based education, although the scientific foundations are collected under the place-based education method. The Ministry of National Education (2018) does not point out a specific method or technique on this subject but uses concepts such as the place of residence and our immediate environment.

According to Şahin (2019), our environment covers all the physical and human elements that shape our lives by affecting and influencing the geographical space through interaction. According to Semken, Ward, Moosavi \& Chinn (2017), the place-based education method effectively teaching the immediate environment is an interdisciplinary teaching and learning method. It is used as a reliable and measurable method of learning 
as it increases the connection of the person with space and place-based education. However, although place-based education is based on historical and domestic teaching philosophies, it draws attention to environmental education, sustainability, and diversity in earth sciences. According to Smith (2002), an essential feature of place-based education is strengthening children's interaction with their environment. It improves students' achievement, but more importantly, it also makes a difference by overcoming students' alienation and abstraction today. Thanks to place-based education, instead of separating children from their environment, they are reconnected with it. Moreover, it enables them to benefit the loyalty and contribution of community members by serving for their environment and communities.

Accordingly, it is vital to prioritize the teaching of the immediate environment in the social studies course. Firstly, the choice of geographical elements must start from the houses where the students reside as well as the school environment. Mainly, increasing the level of knowledge about the place of residence is very important in terms of adaptation to the geographical environment and meeting the daily needs of children. This argument is supported by the "near-to-far" principle and the "global connections" course objectives in the social studies curriculum. Thereupon, schools can bring many innovations to increase students' knowledge about geography (Sağdıç \& Demirkaya, 2015). However, it cannot be adequate to start the subjects from the elementary schools' immediate geography where the foundations of geography education are laid. To this end, teachers may need to take their students out to nature and help them learn by experiencing their geography. The importance of the non-formal school activities mentioned in the second step of local geography education is underlined.

According to Seefelt, Castle \& Falconer (2015), children learn by doing. Teachers, especially the primary school teachers, can help students learn the basic concepts of geography by organizing non-formal school activities and providing experiences through various activities and practices. Hence, children can easily understand the world they live in, learn the surfaces' names and characteristics on Earth, or experience the structure of the day, night, and changing seasons. Also, due to the out-of-school physical activities, understanding the directions makes a difference in learning their addresses. During field trips, children learn the concept of location by positioning themselves and objects within their immediate environment.

The frequency of non-formal school learning activities should be increased; otherwise, geography knowledge cannot go beyond memorization. Many events and phenomena that children can see during their lifetime are trapped in a virtually created classroom setting, so geography is regarded as an unimportant, rote-learned, and unpleasant course by students. However, by considering the natural and human environment geographical issues, students must learn and use the received information in life, not in the classroom. Thence, students must be taken out of the classroom as much as possible, and they should learn by doing (Çifçi \& Dikmenli, 2016). The natural world and the school's geographical environment are integral parts of education (Peterson, McIntyre, \& Heppner, 2018).

Besides, non-formal school learning is an approach that provides concrete opportunities for individuals to experience the immediate environment, nature, and the world. Particularly non-formal school learning activities used in the education of the environment are also important for the social studies course, the primary purpose of which is to raise an environmentally friendly member of society. Whence, the social studies 
course should continuously be supported by non-formal school activities. The traditional education and teaching process cannot be carried out merely using a constructivist approach. Social studies education, one of the main courses of primary education, should not be limited to the classroom setting and should be supported with activities and studies outside the classroom (Çengelci, 2013).

Additionally, considering the connection and interaction with the social studies course, it is necessary to continue learning and teaching processes with learning resources and activities outside the school. The social studies curriculum, created with a constructivist approach, supports social studies with non-formal teaching techniques, primarily environmental issues. Non-formal classroom teaching techniques reinforce students' mental, affective, and psychomotor development. They can be carried out under the themes of nature, and environmental education, field studies, trip-observation in geographical and historical places, research-examination trip, local history, oral history (Tuncel \& Dolanbay, 2017).

According to Ayaş \& Taştan (2015), field studies and trips are unique opportunities for geography. Land works and field trips, which are the essential parts in teaching geography, contribute to students' association with real-life events and geographical concepts. In this regard, thanks to the field studies organized with students, the acquisition of skills become more permanent and solely being exposed to texts and figures in the coursebooks is eliminated. Besides, land works and field trips increase students' interest, curiosity, and motivation, and offers life experiences that will not easily be forgotten.

The trip-observation method is a standard method in social studies courses, in aprticular in teaching the geographical subjects. Students learn more effectively with this technique by embodying knowledge and skills; and will learn new thhings in a fun way and in a permanent fashion. The communication between student-teacher and student-student reaches the peak thanks to this technique. Students are asked to make observations during the implementation of this method, ask questions accordingly, and present them in an unusually broad and diverse classroom environment (Alkan, 2016). As can be understood from these activities, there is a deep relationship between teaching the immediate environment and applying it outside of the school. In this sense, social studies teachers must take into consideration these two elements in teaching geographical subjects.

According to Gençtürk \& Sarpkaya (2015), an essential responsibility of students, who are expected to have many skills and cognitive knowledge today, belongs to teachers who are the most important actors of the education. As the transmitters of values, teachers are also the main characters of the system in preparing children for the future. According to Öztürk (2004), teachers' role in education today results in discussions with increasing technological developments. With the continuous development of information technology in the education field, it is predicted that the teacher's role will decrease or increase. In other words, there is still a dilemma whether the role of the teacher will change.

For successful delivery of lessons, teachers must know self-efficacy and competency in their professions. Teachers may not be successful in a field they have not mastered (Stapp, Prior \& Harmon, 2019). In relation to that, they should have adequate education in their profession; otherwise, they may lack motivation in the classroom (Agboola \& Offong, 2018). 
Today, teachers are expected to have specific proficiencies in conveying geography knowledge and they should pay attention to the following points in the delivery of social studies lessons (Myers, Adler, Brandhorst, Dougan, Dumas, Huffman \& Helmkamp, 2002; Uslu, 2015):

- Be aware of the history, geography, socio-cultural, and economic characteristics of the school environment, be concerned about the main environmental problems, and reflect on the teaching.

- Help students develop the local-regional concept as a tool for interpreting the complexity of the Earth.

- Be sensitive to environmental problems and organize environmental trips for students.

- Help students use geography in their actions to understand the past and present and plan the future.

- Be familiar with the immediate environment in all aspects.

- Reflect the characteristics of the environment to the lesson plan and subjects.

- Help students understand the physical and human characteristics of spaces.

In the social studies course, which is the basis for raising a beneficial and knowledgeable citizen for the future, teachers should be aware of the immediate environment and pay attention to the proximodorsal principle and the effects of non-formal school activities. In this respect, this research aims to investigate the knowledge of social studies teachers regarding the geography they live in and to determine the achievement level of the course objectives and the implementation of non-formal school activities. The current study is significant in showing a scientific way to social studies teachers in teaching geographical subjects to students effectively.

When the literature was reviewed within the scope of research purpose and importance, it was seen that Bartholomaeus (2006) conducted a study on the necessity of place-based education in rural areas in Australia by exploring the meaning and content of place-based education. In his research, by stating that only a few schools gave importance to placebased education and advocated that rural students were educationally disadvantaged, he suggested that place-based education helped students achieve higher academic success and better understand their immediate surroundings. Our research is essential in investigating the expression of local geography in this field and revealing the current situation. Köşker (2012) aimed to reveal geography teachers' views about the place-based teaching approach in his research. With this purpose, a semi-structured interview form about the place-based teaching approach was applied to 258 Geography teachers in Ankara. This study revealed that this research was for geography teachers and should have been done in the social studies course, in which geography education is given at a more fundamental level. In an experimental study by Akkaya (2014) with a place-based teaching approach, the 6th-grade students' academic achievement and attitudes on the social studies lesson were examined using the unit of "Turkey's Sources." According to the results, the experimental group's achievements and attitudes were higher. Since it is an experimental study, the current study meets the necessity of a general study that reveals the geographic information about the environment.

Finally, in a study on local geography, Öner (2016) aimed to reveal teachers' opinions about the immediate environment. In his study, he applied a semi-structured interview form to 101 social studies teachers living in Kayseri and Bolu provinces about the local 
geography. When we compared both studies, our research aims to reveal teachers' opinions about local geography teaching, but the methodology is different from Öner's work. In this direction, our study differs as it determines teachers' existing situations and is prepared under the ministry of education social studies curriculum.

In light of the information above, the problem statement is, "How do social studies teachers reflect the immediate environment in social studies courses?" The following are the four sub-problems of the study:

(1) What is Social Studies teachers' status about collecting information from the primary and secondary information sources about the immediate environment?

(2) What is the status of Social Studies teachers about organizing observation-trip research activities with their students?

(3) What is the status of Social Studies teachers informing their students about the immediate environment?

(4) What is the status of Social Studies teachers giving examples to their students about the immediate environment?

\section{Methodology}

\section{Research Model}

In this scientific research, content analysis, one of the qualitative research methods, was used. Content analysis, according to Büyüköztürk, Kılıç Çakmak, Akgün, Karadeniz \& Demirel (2015), is a collection of regular and systematic data in which the obtained data among the specific categories were reduced to short words and summarized by certain subjects. For the useful application of the technique, it is necessary to determine the purpose of the research, develop a logical structure, define the concepts in the text, describe the coding, and carry out the scientific interpretation.

\section{Research population and sample}

The research population involved the social studies teachers working in Kirıkkale province, and the sample consisted of 38 social studies teachers in the 2018-2019 academic year. In the research, stratified sampling, which is one of the random sampling methods, was used to determine the sample since the population included subgroups by the settlement types. However, in the 4th sub-problem, 1577 students were selected by the stratified sampling method, and data about the students were collected.

Distribution of Immediate Environment Teacher Information Form (IETIF) applied to teachers by specific factors is shown in Table 1, Table 2, and Table 3. 
Table 1. Distribution of Participant Teachers by Gender

\begin{tabular}{lcc}
\hline Gender & $\mathbf{N}$ & $\mathbf{\%}$ \\
\hline Female & 22 & 57.9 \\
Male & 16 & 42.1 \\
\hline Total & $\mathbf{3 8}$ & $\mathbf{1 0 0}$ \\
\hline
\end{tabular}

As seen in Table 1, the participant teachers consisted of $57.9 \%$ (22) female and $42.1 \%$ (16) male teachers.

Table 2. Distribution of Participant Teachers by Settlement Type

\begin{tabular}{lcc}
\hline Settlement Type of the School & N & \% \\
\hline Village & 5 & 13.2 \\
District & 7 & 18.4 \\
Province & 26 & 68.4 \\
\hline Total & $\mathbf{3 8}$ & $\mathbf{1 0 0}$ \\
\hline
\end{tabular}

Table 2 shows that $13.2 \%$ (5) of the participant teachers worked in the village, $18.4 \%$ (7) in the district, and $68.4 \%$ (26) in the province.

Table 3. Distribution of Participant Teachers by Professional Experience

\begin{tabular}{lcc}
\hline Professional Experience & N & \% \\
\hline 0-3 years & 2 & 5.3 \\
4-6 years & 7 & 18.4 \\
7-10 years & 8 & 21.1 \\
10 years and more & 21 & 55.3 \\
\hline Total & $\mathbf{3 8}$ & $\mathbf{1 0 0}$ \\
\hline
\end{tabular}

As seen in Table 3, 5.3\% (2) of participant teachers had 0-3 years of experience, $18.4 \%$ (7) had 4-6 years of experience, $21.1 \%$ (8) had 7-10 years of experience, and $55.3 \%$ (21) had ten years or more experience.

Descriptive data about the participant teachers in the research are shown in Figure 1.

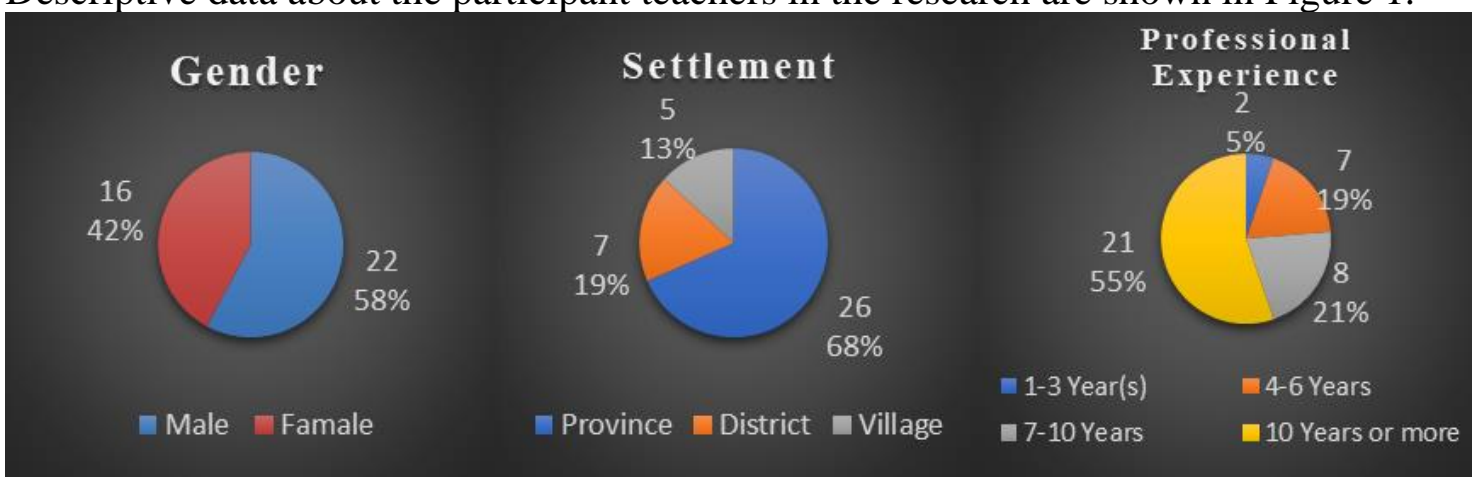

Figure 1. Demographic Features of Participant Teachers in the Research

\section{Data collection tool and data analysis}

The data collection instrument of the study was the "Immediate Environment Teacher Information Form" developed by the researcher. The tool included a "semistructured interview" form created by the teachers. In creating the "Environment Teacher Information Form," firstly, the academic attainment about the immediate environment was determined in the Social Studies Curriculum. Besides, a literature review on the geography of Kirıkkale province was conducted. The items in the Environmental Teacher 
Information Form were created. After taking the opinions of five, including a Turkish language expert, and assessment and evaluation experts to ensure the items' validity and reliability, the form took the final version.

The "Immediate Environment Teacher Information Form" variables were analyzed with Microsoft Excel and Statistical Package for the Social Sciences (SPSS) 17 software. The teachers' responses in the interview form were analyzed by a social studies field expert and researcher. Then, the data were interpreted by the researcher following the literature.

\section{Findings}

\section{The status of social studies teachers getting information about the immediate environment}

Table 4. The Status of Social Studies Teachers Getting Information about the Immediate Environment

\begin{tabular}{|c|c|c|c|c|c|c|c|c|c|}
\hline \multirow[t]{3}{*}{ Variables } & \multirow[t]{3}{*}{ Factors } & \multirow{3}{*}{$\begin{array}{l}\text { Primar } \\
\text { Status } \\
\text { (Partici } \\
\text { Researc } \\
\\
\text { Yes }\end{array}$} & \multicolumn{3}{|c|}{$\begin{array}{l}\text { Source Utilization } \\
\text { tion in Trip-Observation- } \\
\text { Activities) }\end{array}$} & \multicolumn{4}{|c|}{$\begin{array}{l}\text { Secondary Source Utilization } \\
\text { Status } \\
\text { (Reading Written Resources Like } \\
\text { Books-Magazines and Watching } \\
\text { TV Programs Like Documentary, } \\
\text { Film) }\end{array}$} \\
\hline & & & & \multicolumn{2}{|c|}{$\%^{*}$} & \multicolumn{2}{|c|}{$\mathbf{F}$} & \multicolumn{2}{|c|}{$\%^{*}$} \\
\hline & & & No & Yes & No & Yes & No & Yes & No \\
\hline \multirow{2}{*}{ Gender } & Female & 3 & 19 & 13.6 & 86.4 & 8 & 4 & 36.4 & 63.6 \\
\hline & Male & 5 & 11 & 31.3 & 68.8 & 9 & 7 & 56.3 & 43.8 \\
\hline \multirow{3}{*}{$\begin{array}{l}\text { Settlement } \\
\text { Type }\end{array}$} & Village & 2 & 3 & 40 & 60 & 1 & 4 & 20 & 80 \\
\hline & District & 0 & 7 & 0 & 100 & 3 & 4 & 42.9 & 57.1 \\
\hline & Province & 6 & 20 & 23.1 & 76.9 & 13 & 13 & 50 & 50 \\
\hline \multirow{4}{*}{$\begin{array}{l}\text { Professional } \\
\text { Experience }\end{array}$} & $1-3$ years & 1 & 1 & 50 & 50 & 1 & 1 & 50 & 50 \\
\hline & 4-6 years & 0 & 7 & 0 & 100 & 3 & 4 & 42.9 & 57.1 \\
\hline & $7-10$ years & 0 & 8 & 0 & 100 & 3 & 5 & 37.5 & 62.5 \\
\hline & $\begin{array}{l}10 \text { years } \\
\text { and more }\end{array}$ & 7 & 14 & 33.3 & 66.7 & 10 & 11 & 47.6 & 52.4 \\
\hline Total & Total & 8 & 30 & 21.1 & 78.9 & 17 & 21 & 44.7 & 55.3 \\
\hline
\end{tabular}

As shown in Table 4, $8(21 \%)$ participant social studies teachers stated that they participated in the trip-observation-research activities to get information from the primary sources related to the city they live in, and 21 teachers (44\%) obtained information from the secondary sources by reading written materials such as books and magazines or watching TV programs such as documentaries and movies.

As the table shows, there was a high level in favor of male teachers by gender in getting information about the city both in primary and secondary sources. It was also in favor of the teachers whose schools were in villages, and of those who had 1-3 years of professional experience. The participation status of 38 social studies teachers in the tripobservation-research activities is given in Table 5. 
Table 5. the Status of Social Studies Teachers Participating in Trip-ObservationResearch Activities about their City

\begin{tabular}{lll}
\hline Trip-Observation-Research Activities & $\mathbf{f}^{* *}$ & $\mathbf{\%}^{*}$ \\
\hline Immediate Surrounding & 2 & 5.26 \\
Mechanical and Chemical Industry & 2 & 5.26 \\
Weapons Industry Museum & 2 & 5.26 \\
History of Kirkkale & 1 & 2.63 \\
\hline
\end{tabular}

* 38 teachers are targeted. Each percentage (\%) calculation was calculated based on the total number of teachers (38).

** The study was based on teachers who explained their activities among teachers who participated in trip-observation activities. Although some teachers participated in the field trip-observation activity, they did not disclose the type of activity.

The frequency and percentage of the trip-observation-research activities to learn Kirikkale geography is demonstrated in Table 5. According to the findings, the teachers organized their activities in Kırıkkale in 4 main areas: trip and research activities related to the surrounding area, research activities related to the Mechanical and Chemical Industry (MKE), weapons industry museum trip, and research activities in the history of Kirıkkale. Two $(5.26 \%)$ of the teachers expressed that they participated in the environmental and field trips, $2(5.26 \%)$ in the history of the Mechanical and Chemical Industry, $2(5.26 \%)$ in the museums, and $1(2.63 \%)$ searched the history of Kirlkkale. Also, three teachers who searched the history of MKE and the history of Kirikkale stated that they completed these activities for a master's thesis. In this sense, T-2 said, "I was exploring the history of MKE in my master thesis," and T-30 said similarly, "I was searching because of the role of MKE in the establishment of Kirıkkale."

\section{The status of social studies teachers organizing trip-observation-research activities about the immediate environment}

Table 6. The Status of Social Studies Teachers Organizing Trip-Observation-Research Activities for Students

\begin{tabular}{|c|c|c|c|c|c|}
\hline \multirow{2}{*}{ Factors } & \multirow{2}{*}{ Variables } & \multicolumn{2}{|c|}{$\mathbf{F}$} & \multicolumn{2}{|c|}{$\% *$} \\
\hline & & Yes & No & Yes & No \\
\hline \multirow{2}{*}{ Gender } & Female & 1 & 21 & 4.5 & 95.5 \\
\hline & Male & 5 & 11 & 31.3 & 68.8 \\
\hline \multirow{3}{*}{$\begin{array}{l}\text { Settlement } \\
\text { Type }\end{array}$} & Village & 1 & 4 & 20 & 80 \\
\hline & District & 3 & 4 & 42.9 & 57.1 \\
\hline & Province & 2 & 24 & 7.7 & 92.3 \\
\hline \multirow{4}{*}{$\begin{array}{l}\text { Professional } \\
\text { Experience }\end{array}$} & $1-3$ years & 1 & 1 & 50 & 50 \\
\hline & 4-6 years & 1 & 6 & 14.3 & 85.7 \\
\hline & $7-10$ years & 3 & 5 & 37.5 & 62.5 \\
\hline & 10 years and more & 1 & 20 & 4.8 & 95.2 \\
\hline Total & Total & 6 & 32 & 18.8 & 84.2 \\
\hline
\end{tabular}

* 38 teachers are targeted.

Table 6 presents the data regarding the trip-observation-research activity for Kurıkkale geography. Accordingly, 6 of the 38 teachers (18\%) stated that they carried out tripobservation-research activities for their students, while 32 teachers (84.2) expressed that they did not organize any trip-observation-research activities. There was a proportional difference in favor of male teachers by gender. Furthermore, a significant difference was observed in favor of district teachers by settlement type and 1-3 years of experience. The frequency and percentage of the trip-observation research activities carried out by teachers are shown in Table 7. 
Table 7. Frequency of Trip-Observation-Research Activities Organized by Teachers

\begin{tabular}{llll}
\hline & & f & \%* \\
\hline \multirow{4}{*}{ Activity Type } & Immediate environment trips & 3 & 7.89 \\
& Environmental history and & 2 & 5.26 \\
& cultural trips & 1 & 2.63 \\
\hline \multirow{4}{*}{ Activity Number } & Province-district Trips & 32 & 84.2 \\
& Never & 5 & 13.15 \\
& Once a year & 1 & 2.63 \\
& Twice a year & 0 & 0 \\
\hline 3 38 teachers are targeted. Each percentage (\%) calculation was calculated based on the total number of \\
teachers (38).
\end{tabular}

As can be seen in Table 7, 3 teachers $(7.89 \%)$ organized activities to familiarize themselves with the immediate environment, 2 (5.26\%) carried out the environmental history and cultural trips for their students, and $1(2.63 \%)$ planned activities to promote the province-district. Also, 32 of the teachers $(84.2 \%)$ stated that they did not plan any trip-observation-research activities related to the Kırıkkale geography, while 5 (13.15\%) of the teachers carried out any trip-observation-research activities once a year and $1(2 \%$, 63) twice a year. None of the teachers indicated that they did not plan three or more activities per year in the trip-observation-research activity to teach the geography of Kirıkkale.

\section{The status of social studies teachers giving information about their immediate environment}

Table 8. the Status of Social Studies Teachers Giving Information about the Geography of Kirıkkale

\begin{tabular}{llcccc}
\hline \multirow{2}{*}{ Factors } & Variables & Yes & No & Yes & No \\
\cline { 3 - 6 } Gender & Female & 20 & 2 & 90.9 & 9.1 \\
& Male & 15 & 1 & 93.8 & 6.3 \\
\hline \multirow{2}{*}{ Settlement Type } & Village & 5 & 0 & 100 & 0 \\
& District & 6 & 1 & 85.7 & 14.3 \\
& Province & 24 & 2 & 92.3 & 7.7 \\
\hline \multirow{2}{*}{ Professional } & 1-3 years & 2 & 0 & 100 & 0 \\
Experience & 4-6 years & 6 & 1 & 85.7 & 14.3 \\
& 7-10 years & 8 & 0 & 100 & 0 \\
\hline Total & 10 years and & 19 & 2 & 90.5 & 9.5 \\
\hline
\end{tabular}

* 38 teachers are targeted.

In Table 8, the data shows the social studies teachers' status giving information to their students about the environment in which they live. Accordingly, 35 out of 38 teachers (92\%) stated that they provided their students with information about their environment. A high rate is seen among male teachers, the teachers working in the village, and the teachers with 1-3 years and 7-10 years of professional experience. Another important data was related to the types of geographical topics that teachers conveyed about their immediate environment. In this context, the topics described by the teachers are displayed in Table 9. 
Table 9. the Subjects/Topics that Teachers Describe Kırıkkale Province

\begin{tabular}{llll}
\hline $\begin{array}{l}\text { Geographical } \\
\text { Areas }\end{array}$ & Sub-disciplines & $\mathbf{f}^{*}$ & $\mathbf{0}^{*}$ \\
\hline & Soil Structure & 2 & 5.26 \\
Physical & General physical structure & 4 & 10.52 \\
Geography & Vegetation & 9 & 23.68 \\
& Landforms & 15 & 39.47 \\
& Climate & 19 & 50 \\
& Total (Physical Geography) & $\mathbf{2 5}$ & $\mathbf{6 5 . 7 8}$ \\
\hline & Trade & 1 & 2.63 \\
& Tourism & 1 & 2.63 \\
& Population & 1 & 2.63 \\
Human and & Underground resources & 1 & 2.63 \\
economic & Above-ground resources & 1 & 2.63 \\
geography & Industry & 2 & 5.26 \\
& Settlement Area & 2 & 5.26 \\
& Human characteristics & 4 & 10.52 \\
& Culture and history & 5 & 13.15 \\
& Economic activities & 8 & 21.05 \\
& Agriculture & 8 & 21.05 \\
& Total (Human and economic & $\mathbf{1 7}$ & $\mathbf{4 4 . 7 3}$ \\
\hline \multirow{2}{*}{ Location } & geography) & 3 & 7.89 \\
\hline
\end{tabular}

* 38 teachers are targeted. Each percentage (\%) calculation was calculated based on the total number of teachers (38).

In Table 9, there are topics about the geography of Kirikkale described by the teachers during the lesson. In the Educational Informatics Network (EBA, 2013), the platform of the Ministry of National Education, the subjects about the description of the immediate environment, were divided into three categories as physical geography, human and economic geography, and location, which is the same categorization in this study.

To the analysis results, $5.26 \%$ of teachers (2) stated that they taught the soil structure related to physical geography, $10.52 \%$ of teachers (4) about the general physical structure, $23.68 \%$ of teachers (9) about the vegetation on Earth, 39.47\% of teachers (15) about the landforms, and $50 \%$ of teachers (19) talked about the climate. What is more, $2.63 \%$ of the teachers explained the trade-related human and economic geography (1), 2.63\% about tourism (1), 2.63\% about the population issues (1), $2.63 \%$ about underground resources (1), $2.63 \%$ about above-ground resources (1), 5.26\% about the industrial issues (2), $5.26 \%$ about the settlement areas (2), 10.52\% about human characteristics in general (4), $13.15 \%$ about culture and history (5), 21.05\% about economic activities (8), and $21.05 \%$ (8) about agriculture, and also $7.89 \%$ (3) of the teachers stated that they taught the latitudelongitude subject. T-5 told, "I give information about the climate, landforms (physical characteristics), agricultural products, but generally about the Central Anatolia rather than Kırıkkale." T-22 said, “...whether or not Kirıkkale has historical places (specifically in Keskin district)."

Some teachers expressed that they taught mostly the climate subject regarding the physical geography features, whereas, among the geographical features of human geography, mostly the settlement and economic activities, the latitude and longitude subjects in terms of the location were taught. That said, teachers usually described the 
physical geography characteristics related to their immediate environment $(65.78 \%)$, followed by human and economic geography (44.73\%) and location characteristics $(7.89 \%)$.

\section{The status of social studies teachers talking about the place where students live}

Table 10. the Status of Social Studies Teachers Explaining the Geography of Kirıkkale

\begin{tabular}{llcccc}
\hline \multirow{2}{*}{ Factors } & \multirow{2}{*}{ Variables } & \multicolumn{2}{c}{$\mathbf{f}^{*}$} & \multicolumn{3}{c}{ \% $^{*}$} \\
\cline { 2 - 6 } Gender & Female & Yes & No & Yes & No \\
& Male & 16 & 6 & 72.7 & 27.3 \\
\multirow{3}{*}{ Settlement Type } & Village & 16 & 0 & 100 & 0 \\
& District & 5 & 0 & 100 & 0 \\
& Province & 5 & 2 & 71.4 & 28.6 \\
\multirow{3}{*}{ Professional Experience } & 1-3 years & 22 & 4 & 84.6 & 15.4 \\
& 4-6 years & 2 & 0 & 100 & 0 \\
& 7-10 years & 6 & 1 & 85.7 & 14.3 \\
& 10 years and more & 5 & 3 & 62.5 & 37.5 \\
\hline Total & Total & 19 & 2 & 90.5 & 9.5 \\
\hline
\end{tabular}

* 38 teachers are targeted.

Table 10 shows the status of examples of geographical features. According to the results, $84.2 \%$ of the teachers stated that they gave examples of their environment, while $15.8 \%$ did not. The majority of male teachers scored high by the gender variable. Similarly, most teachers whose school was located in the village, and the teachers who had 1-3 years of professional experience had higher rates. Another important finding of the study was the teachers' examples of their environment's geographical features during the lesson. Those examples are given in table 11.

Table 11. the Frequency Table of the Examples Given by the Teachers in the Classroom about Kirikkale

\begin{tabular}{llll}
\hline Geographic Areas & Geographical Examples (Kırıkkale) & f & \% \\
\hline & Terrestrial climate & 12 & 31.57 \\
Physical & Kizılırmak & 9 & 23.68 \\
Geography & Plain and plateau & 7 & 18.42 \\
& Mountains & 6 & 15.78 \\
& The steppe & 2 & 5.26 \\
& Natural assets (cave) & 1 & 2.63 \\
\hline & Agricultural products in Kırıkkale & 21.05 \\
& TÜPRAŞ (Central Anatolian Oil Refinery) & 8 & 13.15 \\
& MKE (Mechanical and Chemical Industry) & 5 & 10.52 \\
Human and & Çeşnigir Bridge & 4 & 10.52 \\
economic & Kapulukaya Dam & 4 & 7.89 \\
geography & Local food & 3 & 7.89 \\
& Weapons Industry Museum & 3 & 5.26 \\
& Provincial-district names & 2 & 2.63 \\
& Local games & 1 & 2.63 \\
& Delice grape & 1 & 2.63 \\
& Keskin fried meat & 1 & 2.63 \\
& Haci Taşan & 1 & 2.63 \\
& Settlement Type & 1 & 2.63 \\
& Historical Assets & 1 & 2.63 \\
\hline Location & Special location & 1 & 10.52 \\
\hline
\end{tabular}


Table 11 shows the geographical examples of the social studies teachers regarding their environment. According to these results, when we listed the geographical elements of physical geography used by the teachers, we found that $31.57 \%$ of teachers gave the example of terrestrial climate-related, $23.68 \%$ the example of Kizllirmak, $18.42 \%$ the plain and plateau examples in Kırıkkale, $15.78 \%$ the mountains in Kırıkkale, 5.26\% the steppe climate, and $2.63 \%$ the example of natural sources. In terms of human geography, $21.05 \%$ of the teachers mentioned about the agricultural products grown in Kirlkkale, $13.15 \%$ about TÜPRAŞ (Central Anatolian Oil Refinery), 10.52\% about the Mechanical and Chemical Industry, 10.52\% about Cesnigir Bridge, $7.89 \%$ about Kapulukaya Dam, $7.89 \%$ about local foods, $5.26 \%$ about weapons industry museum, 2,63\% about provincial-district names, 2,63\% about local games, $2.63 \%$ about Delice grape, $2.63 \%$ about Keskin fried meat, 2.63\% about Hac1 TAŞAN, 2.63\% about settlement types, $2.63 \%$ about historical assets, and $10.52 \%$ about special location in their lessons.

T-24 expressed, "I explain climate characteristics. I give information about settlement types by climate and agricultural products." T-30 said, "It has steppe vegetation and terrestrial climate. The agricultural products include wheat, barley, sunflower, sugar beet, and various vegetables and fruits. They have an important place in the economy." T-5, on the other hand, described as "I stated that the landforms are flat, wide lands consisting of plains and continental climate is seen.".

Table 12. The Status of Social Studies Teachers Giving Examples of their Immediate Environment

\begin{tabular}{llcc}
\hline Variables & Factor & f & \% \\
\hline The status of social studies teachers giving & Yes & 1044 & 66.2 \\
examples from the city they live in & No & 533 & 33.8 \\
\hline & Total & $\mathbf{1 5 7 7}$ & 100 \\
\hline
\end{tabular}

Table 12 shows the status of social studies teachers giving examples of the city they live in. Accordingly, $66.2 \%$ of the students expressed that their teachers gave examples, and $33.8 \%$ stated that they did not give any examples of their environment. That being said, as seen in Table 10, 84.2\% indicated that they gave an example to the same question, and $15.8 \%$ did not give any examples about their environment. Here, there is a contradiction between teachers' and students' response rates.

\section{Conclusion \& Discussion}

According to the research results, it is concluded that:

1) $42.1 \%$ of the participants are male, and $57.9 \%$ are female teachers. In addition, $13.2 \%$ of the schools are in the village, $18.4 \%$ in the district, and $68.4 \%$ in the province. In terms of professional experience, $5.3 \%$ of teachers have $0-3$ years of experience, $18.4 \%$ have $4-6$ years of experience, $21.1 \%$ have $7-10$ years of experience, and $55.3 \%$ have ten years and more experience. It would be fair to say looking at the findings that the sample is suitable to represent the population.

2) Only $21 \%$ of the social studies teachers articulated that they participated in the trip-observation or research activity related to their place of residence, and preferred to learn the geography of Kirıkkale from the primary information sources. It is seen that the current participation rate is very low.

3 ) In the study, $18.8 \%$ of the teachers underlined that they carried out excursionobservation-research activities with their students, and due to the low rate, it was 
understood that the students' knowledge about their environment is mostly based on written and visual sources. Öner (2016), Köşker \& Karabağ (2012), and Öztürk (2004) also emphasized that teachers generally do not carry out excursionobservation activities in their schools, which shows parallelism with the current results. Nevertheless, Y1ldırım (2012) found that social studies teachers mostly organize such activities.

4) Although social studies teachers benefit from secondary information sources, it is still insufficient. In other words, most of the teachers do not benefit from any source related to where they live. It causes teachers to misrepresent their province to their students.

5) There is also a discrepancy between the percentage of teacher examples and their students, which might stem from two inferences. The first is that teachers claim that they give information about their geography, intending to defend themselves due to internal or external pressures. The second may stem from the fact that the examples are given during the lesson, but the students might not listen to the teacher. Ince (2015) found that the students do not know the geographical environment, and he also accentuated that with the delivery of geography subjects in the lesson, the students' interest in their immediate surroundings increased.

6) As for gender variable, male teachers benefited more from primary (travelobservation-research activity) and secondary (written and visual material) information resources. The reasons for male teachers learn better about their immediate surroundings may be biological, environmental, and evolutionary. Among those factors, there is also a concern for the environment, gender pressure, and parental expectations. Lawrod (2010) also supported our research by indicating that males had better spatial skills than females, which might stem from evolutionary, social, and cultural fields. Öner (2016) also supports our research by stating that male teachers engage in more immediate environment activities.

7) The village teachers benefit more from primary (travel-observation-research activity) and secondary (written and visual material) information sources. It can be suggested that the intertwined nature of village schools attract teachers and stimulate their curiosity and desire to explore their surroundings. Ben-Chaim, Lappan, \& Houang (1988) carried out a 3-week experimental study on spatial intelligence with 1000 elementary school students and 21 teachers and found that the students living in the city center got lower scores than other students, and males had statistically significant higher scores than females, which supported the findings of the current study. In a study by Nagra (2010), it was seen that teachers living in the city center have high environmental differences, which does not show parallelism with our research.

8) District teachers frequently participate in environmental excursion-observationresearch activities with their students. The main reason is that the district teachers are generally more experienced than the village students, and as a result, they tend to do activities with their students rather than explore the environment.

9) Teachers with 1-3 years of experience benefit more from primary (travelobservation-research activity) and secondary (written and visual material) sources by the professional experience variable. Nonetheless, in the study, male teachers and teachers with 1-3 years of experience participate in out-of-school teaching activities at a higher rate. The reasons for this include dynamism, interest in profession and environment, desire to discover the new places they are appointed to, and community orientations. In their study, Guay \& McDaniel (1977), Linn \& 
Petersen (1985), and Ehrlich, Levine \& Goldin-Meadow (2006) found that males had higher spatial skills than females, which is parallel with the current findings.

\section{Implications}

- It is observed that there is a lack of non-formal school activities that will contribute to the students' experiential learning of the geographical features of their immediate surroundings (e.g., trip-observation-research activities). The quality of non-formal school activities should be increased, and teachers should organize purposeful school activities. Teachers support environmental education outside of school but face various challenges. Thereupon, environmental education should be supported by in-service and vocational training in universities and during their careers at schools.

- Although both students and teachers provided examples of where they lived, it was not sufficient. At this point, teachers should use more tools and equipment to embody the course objectives, and at the same time, they should be involved in the geography in person.

- Local, regional, national, and global geographic equipment is available in schools. Hence, the active use of lesson tools such as books, maps, movies, and CDs will enhance social studies education quality. It was observed that teachers do not make good use of primary and secondary information sources. It should also be noted that teachers who do not benefit from these resources will not perform effective type of teaching. Therefore, social studies teachers are expected to use information sources about their environment, even if it is not their hometown.

- This study was carried out in Turkey, and although there are no courses related to the "immediate environment," these course objectives are taught in the curriculums of life sciences, social studies, and geography courses. However, thanks to the elective course titled "My City ......" introduced in the secondary school curriculum of the 2018-2019 academic year, students started to acquire more comprehensive and organized sort of information about their immediate environment. Even though there is still not a specific coursebook and curriculum for every province, it is predicted that they will be ready for use in the 2020-2021 academic year.

\section{Acknowledgement}

This paper was produced from the thesis "An Analysis on Students' Local Geography Knowledge in Social Studies Course" submitted by Gün Erol ŞAHIN and supervised by Çağrı ÖZTÜRK DEMİRBAŞ.

\section{References}

Agboola, B., \& Offong, D. E. (2018) Occupational incentives and teacher retention in private secondary schools in Akwa lbom state, Nigeria. Journal of Teacher Education and Educators, 7(3), 263-277.

Akkaya, M. (2014). Place-based teaching approach in social studies (Published Doctoral Thesis). Gazi University, Institute of Educational Sciences, Ankara.

Aksoy, B., \& Ablak, S. (2019). An evaluation of map literacy of social studies preservice teachers. Participatory Educational Research, 6(2), 158-168. DOI: 10.17275/per.19.19.6.2 
Alkan, V. (2016). Teaching Methods and Techniques in Social Studies Education. S. Şimşek (Eds.) Social Studies Teaching for Social Studies and Classroom Teachers. Ankara: Pegem Academy.

Ayas, C., \& Taştan, B. (2015). Geographical areas in out-of-school social studies education. A. Şimşek and S. Çakmakçı. (Eds.) Out-of-school Social Studies Education. Ankara: Pegem Academy.

Bartholomaeus, P. A. (2006). Some rural examples of place-based education. International Education Journal, 7(4), 480-489.

Ben-Chaim, D., Lappan, G., \& Houang, R. T. (1988). The effect of instruction on spatial visualization skills of middle school boys and girls. American Educational Research Journal, 25(1), 51-71.

Büyüköztürk, Ş., Çakmak, E. K., Akgün Ö. E., Karadeniz, Ş. ve Demirel, F. (2015). Scientific research methods. Ankara: Pegem Academy.

Çengelci, T. (2013). Social Studies teachers' opinion about out-of-classroom learning. Educational Sciences in Theory and Practice, 13(3), 1823-1841. doi: 10.12738/estp.2013.3.1410

Çifçi, T., \& Dikmenli, Y. (2016). Geography teachers' views on out-of-school geography education, Ahi Evran University Kırşehir Education Faculty Journal (KEFAD), 17(1) 363-382.

Doğanay, H., \& Doğanay, S. (2015). An introduction to geography. Ankara: Pegem Academy.

EBA (2013). Geographical features of our immediate environment. Retrieved from https://www.eba.gov.tr/video/izle/5347582f5360593a84c6b9df5f58dfea992902d $\underline{09 \mathrm{c} 001}$

Ehrlich, S. B., Levine, S. C., \& Goldin-Meadow, S. (2006). The importance of gesture in children's spatial reasoning. Developmental psychology, 42(6), 1259.

Gençtürk, E. \& Sarpkaya, G. (2015). Qualifications of social studies teachers, M. Safran (Eds.) Social Studies Education. Ankara: Pegem Academy.

Guay, R. B., \& McDaniel, E. D. (1977). The relationship between mathematics achievement and spatial abilities among elementary school children. Journal for Research in Mathematics Education, 211-215.

Kosker, N. (2012). Teachers' views on place-based teaching approach in geography education. (Published Doctoral Thesis). Gazi University Institute of Educational Sciences, Ankara.

Köşker, N., \& Karabağ, S. (2012). Teachers' views on place-based education approach in the education of geography. The Journal of Turkish Social Research, 2 (163).

Lawton, C. A. (2010). Gender, spatial abilities, and wayfinding. In Handbook of gender research in psychology (pp. 317-341). Springer, New York, NY.

Linn, M. C., \& Petersen, A. C. (1985). Emergence and characterization of sex differences in spatial ability: A meta-analysis. Child development, 1479-1498.

Myers, C. B., Adler, S., Brandhorst, A., Dougan, A. M., Dumas, W., Huffman, L. \& Helmkamp, C. J. (2002). National standards for social studies teachers. Silver Spring, Md: National Council For The Social Studies.

Nagra, V. (2010). Environmental education awareness among school teachers. The Environmentalist, 30(2), 153-162. DOI: 10.1007 / s10669-010-9257-X

Öner, G. (2016). Teaching local geography in social studies: evaluation of teachers' opinions. (Unpublished master dissertation). Abant İzzet Baysal University Institute of Educational Sciences Primary Education Department, Bolu.

Öztürk, Ç. (2004). Secondary school geography teachers' ability to use teaching methods DOI techniques. Gazi University, Kırşehir Education Faculty. 5 (2), 75-83. 
Öztürk Demirbaş, Ç. \& Şahin, G. E. (2019, April). Geographical information in social studies textbooks from local to global.1st international Cappadocia congress of philosophy and social sciences (CAPASS2019). Nevşehir Hacı Bektaşi Veli University, Nevşehir. Retrieved from http://www.capasscongress.com/wpcontent/uploads/2019/12/CAPASS2019-Proceedings-ISBN-2.pdf

Peterson, S. S., McIntyre, L., \& Heppner, D. (2018). Northern rural and indigenous teachers' experiences and perceptions of rural teaching and teacher education. Journal of Teacher Education and Educators, 7(3), 189-205.

Sağdıç, M., \& Demirkaya, H. (2015). Learning settings based on geographical places in social studies education. R, Sever, and E, Koçoğlu (Eds.) Spatial Learning Environments in Social Studies. Ankara: Pegem Academy.

Seefelt, C. Castle, S., \& Falconer, R. C. (2015). People, places, environments: geography. S. Ç. Keskin (trans.) Social Studies Education for Preschool and Primary Scholl Students, Ankara: Nobel Publications

Semken, S., Ward, E. G., Moosavi, S., \& Chinn, P. W. U. (2017). Place-based education in geoscience: Theory, Research, Practice and Assessment, Journal Of Geoscience Education, 65:4, 542-562. doi: 10.5408/17-276.1

Smith, G. A. (2002). Place-based education: learning to be where we are. Phi Delta Kappan, 83(8), 584-594. doi: 10.1177/003172170208300806

Stapp, A., Prior, L., \& Harmon, C . (2019). The relationship between wellness and physical activity integration coursework and preservice teachers' self-efficacy. Journal of Teacher Education and Educators, 8 (3), 247-264.

Şahin, G. E. (2019). Determination of local geographical knowledge levels of students in social studies, (Unpublished master dissertation). Kırşehir Ahi Evran University Institute of Social Sciences Turkish and Social Studies Education Department, Kırşehir.

Şahin, G. E., \& Öztürk Demirbaş, Ç. (2019, October). Local geographical knowledge levels of students in social studies course: kirlkkale example. II. International Congress of Geographical Education (ICGE2019). Eskişehir Osmangazi University, Eskişehir. Retrieved from http://2019.ucek.org/bildiriler-kitabi/

The Ministry of National Education (MoNE) (2018). Social studies curriculum: primary and secondary schools 4th, 5th, 6th and 7th grades. Ankara: Public Books.

The Ministry of National Education (MoNE) (2019). Social studies coursebook 6th grade [Secondary and Imam Hatip Secondary School], Ankara: Public Books.

Tuncel, G., \& Dolanbay, H. (2017). Social studies education with out-of-class techniques. R. Sever, M. Aydın, and E. Koçoğlu (Eds.) Alternative Approaches to Social Studies Education. Ankara: Pegem Academy.

Uslu, S. (2015). Qualifications of Social Studies Teachers, C. Dönmez, and K. Yazıc1 (Eds.). Social Studies Teaching. Ankara: Pegem Academy.

Y1ldırım, R. (2012). Study of application for excursion observation method in primary school 2nd-grade social studies (Unpublished master dissertation). Afyon Kocatepe University, Institute of Social Sciences Primary Education Department. Afyonkarahisar. 